Michał Wenklar

Akademia Ignatianum w Krakowie

Instytut Pamięci Narodowej

\title{
Między obroną wolności a drogą do rewolucji. Strajk nauczycielski 1937 roku
}

Osiemdziesiąt lat temu, 29 września 1937 r., Komisariat Rządu na m. st. Warszawę zawiesił Zarząd Główny Związku Nauczycielstwa Polskiego, a dzień później do zarządzania związkiem został wyznaczony rządowy kurator. Odpowiedzią był strajk okupacyjny pracowników zarządu, wsparty przez część terenowych struktur ZNP. Decyzja o zawieszeniu ZG zapadła na podstawie zarzutów o wspieranie tendencji antypaństwowych czy wręcz komunistycznych przez nauczycielski związek, a poprzedziła ją tzw. sprawa „Płomyka". Jeden z numerów tego adresowanego do młodzieży pisma w 1936 r. został poświęcony Związkowi Sowieckiemu. Poddany szerokiej krytyce ZNP wytoczył wówczas proces krakowskiemu "Ilustrowanemu Kurierowi Codziennemu", który jako pierwszy zaatakował nauczycielski związek. Proces ten przegrał. Kilka miesięcy później do gmachu ZNP przy ul. Smulikowskiego w Warszawie wkroczył kurator, a reakcją na to był strajk zainicjowany przez zatrudnione w Wydziale Wydawnictw ZNP Wandę Wasilewską i Janinę Broniewską.

Wydarzenie to bywa postrzegane jako element walki w obronie swobód obywatelskich przed autorytarnymi czy nawet faszystowskimi tendencjami obozu sanacyjnego. Argumenty strony dostrzegającej wpływy komunistyczne w związku czy propagandowy charakter sowieckiego numeru "Płomyka" są bagatelizowane lub wręcz wyśmiewane. Pogląd taki utrwalają publikowane wspomnienia organizatorek strajku i redaktorek feralnego 
"Płomyka" Wandy Wasilewskiej i Jadwigi Broniewskiej¹ (stanowiące jedno z głównych źródeł na ten temat), a także części ówczesnych polityków, również z obozu rządzącego, związanych z oświatą ${ }^{2}$. Ale jest on obecny i we współczesnych opracowaniach, a nawet w bieżącej publicystyce. W opublikowanym na stronie "Krytyki Politycznej" artykule Strajk przeciw złej zmianie autorka - podpisująca się jako "socjolożka i feministka" - przyrównuje strajk z 1937 r. do sprzeciwu ZNP wobec polityki „Prawa i Sprawiedliwości" z 2017 r., sugerując podobnie represyjny charakter działań władz sanacji i współczesnego rządu: „Gdy czytamy dziś Historię jednego strajku Wandy Wasilewskiej, jego opis w Tamtym brzegu mych lat Janiny Broniewskiej czy wspomnienie Seweryna Maciszewskiego, opublikowane przez jego syna porównania ze współczesnością są nieuniknione"3.

Pomijając kwestię sporu obecnego rządu z ZNP, warto powrócić do tego sprzed osiemdziesięciu lat i przypomnieć nie tylko przebieg strajku i to, jak go zapamiętali sami strajkujący, ale też argumenty strony rządowej. Należy również zadać pytanie o stopień - pomijanych raczej w literaturze przedmiotu - związków strajkujących z ruchem komunistycznym.

\section{Sowiecki „Płomyk"}

Feralny numer "Płomyka" ukazał się 2 marca 1936 r. Okładkę zdobiło zdjęcie uśmiechniętych dziewczynek, podpisane "dziewczęta sowieckie". W środku znalazły się m. in. artykuły o moskiewskim teatrze dla dzieci Natalii $\mathrm{Sac}^{4}$, list rzekomego pioniera do angielskiego skauta z apologią współzawodnictwa pracy, artykuły o tajdze, ale też o śmierci na zesłaniu i Polakach na Kremlu.

Czy numer ten miał charakter propagandowy? Janina Broniewska napisze później: „Z latami narosła legenda i wśród lewicy na temat owego numeru "Płomyka», że był aż tak rewolucyjny, jak niestety nie był"5. Zdaniem Czesława Wycecha, ówczesnego lewicowego działacza ZNP - równolegle

1. W. Wasilewska, Historia jednego strajku, Warszawa 1950; J. Broniewska, Tamten brzeg mych lat, Warszawa 1979.

2. S. W. Maciszewski, Kartka z dziejów kryzysu w ZNP (1937-1938), "Rozprawy z Dziejów Oświaty" XLI 2002, s. 243-253; Cz. Wycech, Wspomnienia 19o5-1939, Warszawa 1969 .

3. I. Desperak, Strajk przeciwko złej zmianie, http://krytykapolityczna.pl/kultura/ historia/strajk-przeciwko-zlej-zmianie/, (26.06.2017).

4. Wówczas jeszcze na wolności. Półtora roku później, 21 VIII 1937, Natalia Sac została zatrzymana i skazana na 5 lat łagrów. Powróci z zesłania dopiero w 1958.

5. J. Broniewska, Tamten brzeg..., dz. cyt., s. 100. 
polityka SL, wywodzącego się z PSL „Wyzwolenie" - materiał był dostosowany do wymogów programowych i wybrano do niego najbardziej apolityczne tematy. Przyczyną późniejszej krytyki była, jego zdaniem, okładka: "A na okładce fotografia uśmiechniętego dziecka radzieckiego. I to stało się kamieniem obrazy. Bo uśmiechnięte dziecko - to oczywiście propaganda komunizmu"6. Podobnie oceniał to Seweryn Maciszewski, były legionista, wówczas naczelnik Wydziału Prezydialnego w Ministerstwie Wyznań i Oświecenia: „Roześmianą buzię dziewczynki radzieckiej na okładce tego numeru uznano za niebezpieczną propagandę komunistyczną. Nonsens był oczywisty, ale pisma katolickie i endeckie, którym ZNP był więcej niż solą w oku, rzuciły się ze wściekłym ujadaniem i na organizację i na czasopisma"7.

Obok wesołej antybiurokratycznej humoreski Michaiła Zoszczenki ${ }^{8}$ (tak, tak, to ten od opowiadań o Leninie ${ }^{9}$ ), przyrodniczego artykułu o taj$\mathrm{dze}^{10} \mathrm{czy}$ fragmentów patriotycznego wiersza Or-Ota o syberyjskich zesłańcach $^{11}$ znalazły się tam jednak również treści, które można potraktować jako co najmniej próbę budowy pozytywnego wizerunku ZSRS. Pamiętajmy, że władze polskie zdawały sobie sprawę zarówno z totalitarnego, represyjnego charakteru tego państwa, a było to już po rozpoczęciu fali Wielkiego Terroru, jak i ze stałego zagrożenia, jakie stanowiło ono wobec Polski z prowadzonej przez ZSRS akcji wspierania nielegalnych partii komunistycznych w krajach sąsiednich, również w Polsce, z inicjowania tendencji separatystycznych na Białorusi, z zakusów na Kresy czy z żywionych wciąż planów światowej rewolucji, dla której Polska była pierwszą przeszkodą.

Nietrudno się dopatrzeć na łamach tego numeru "Płomyka" licznych pozytywnych odniesień do systemu sowieckiego, wręcz wywyższanego nad inne. Na przykład przy artykule o teatrze dla dzieci znajdzie się pochwała sowieckiej polityki kulturalnej ze słowami: „Oczywiście w Rosji, gdzie wszystkie muzea, zbiory, biblioteki i teatry są instytucjami państwowymi, jest to łatwiejsze do przeprowadzenia niż gdzie indziej"12. W liście

6. Cz. Wycech, Wspomnienia..., dz. cyt., s. 248.

7. S. Matuszewski, Kartka z dziejów..., dz. cyt., s. 249.

8. M. Zoszczenko, Kalosz (humoreska), "Płomyk", 2 III 1936.

9. Wiele wydań, m.in.: M. Zoszczenko, Opowiadania o Leninie, Warszawa 1970.

10. W. Lindeman, Tajga, "Płomyk", 2 III 1936.

11. Or-Ot [Artur Oppman], List z Sybiru, "Płomyk", 2 III 1936.

12. A. Bruski, Teatr dla dzieci w Moskwie, "Płomyk", 2 III 1936. 
pioniera do skauta przeczytamy tłumaczenie polityki militarystycznej ZSRS („wszak musimy mieć silne wojsko dla obrony swej ojczyzny od wrogów zewnętrznych i wewnętrznych") oraz uzasadnienie polityki represji i nadludzkiego wysiłku robotników. Biorąc pod uwagę znane nam dziś dane o ofiarach wielkich sowieckich inwestycji (np. budowa kanału białomorskiego - wg różnych źródeł od 25 do 250 tys. ofiar), złowieszczo brzmią słowa: „czemżeż jest pojedynczy człowiek, czem jest nawet setka, nawet tysiąc ludzi. Człowiek ginie, dzieło jego pracy pozostaje. Gdyby nie gigantyczny wysiłek mózgu naszych inżynierów i mięśni naszych robotników, gdyby nie tysiące poległych przy pracy, to czyż mielibyśmy taki Magnitogorsk, taki Dnieprostroj, albo Kanał Bałtycko-Białomorski"13. Dodajmy, że listu tego nie napisał oczywiście żaden pionier. Wasilewska wspominała: "Przychodził do nas bardzo miły facet, brat literata Szczęsnego, który miał kłopoty finansowe i od czasu do czasu coś nam pisywał. Zaproponowaliśmy mu aby napisał coś dla dzieci o dzieciach. On wybrał sobie wówczas tę śliczną formę: List pioniera radzieckiego do skauta angielskiego"14. Jak się okazuje, w przeciwieństwie do formy treść nie była czysto dziecięca. Zwieńczeniem numeru był kącik rozrywkowy, a tam w jedną z szarad zręcznie wpleciono nazwisko "sławnego komunisty, zmarłego wodza rewolucji" - Włodzimierza Lenina ${ }^{15}$.

Artykuły te nie pozostały niezauważone. Pierwszy atak na poświęcony ZSRS numer „Płomyka" padł na łamach krakowskiego "Ilustrowanego Kuriera Codziennego" (zwanego potocznie "Ikacem"). Artykuł zatytułowany Szaleństwo czy zbrodnia? Młodzież szkolna w Polsce truje się jadem bolszewizmu ukazywał ten numer jednoznacznie jako przykład prosowieckiej propagandy: „To już propaganda, za którą autor dostanie chyba order Czerwonej Gwiazdy, całość opracowana sprytnie, chytrze, perfidnie, pełna powiedzeń fascynujących, zdań, które mogą mocno sugerować umysły dziecięce"1"16. Rozpoczęła się obecna w kilku tytułach polemika prasowa. Krytyka, zapoczątkowana przez sanacyjnego raczej „Ikaca", płynęła

13. Jak pracuja w ZSRR. List pioniera (skauta) rosyjskiego do angielskiego skauta, „Płomyk", 2 III 1936.

14. Wspomnienia Wandy Wasilewskiej (nagrane w Zakładzie Historii Partii przy KC PZPR w styczniu 1964 r.), s. 132 (udostępnione przez M. Korkucia, kopia w posiadaniu autora).

15. Szarada 2, „Płomyk", 2 III 1936.

16. Szaleństwo czy zbrodnia? Młodzież szkolna w Polsce truje się jadem bolszewizmu, "Ilustrowany Kurier Codzienny", 7 III 1936. 
głównie z pism konserwatywnych, narodowych i katolickich. Bronili za to "Płomyka" m.in. współfinansowany przez ZNP i związany z sanacyjną lewicą "Dziennik Poranny" oraz socjalistyczny "Robotnik". 7 marca Komisarz Rządu nakazał konfiskatę części nakładu tego numeru „Płomyka”, decyzja ta nie została jednak zatwierdzona przez sąd i skonfiskowane egzemplarze wróciły do wydawcy ${ }^{17}$.

W odpowiedzi na prasowe ataki wydawcy "Płomyka" - prezes ZNP Jan Kolanko, odpowiedzialny za działalność wydawniczą związku Stanisław Machowski i redaktor pisma Mieczysław Kotarbiński - wytoczyli „Ikacowi” proces o „postępowanie mogące narazić na utratę zaufania potrzebnego do pełnienia ich działalności publicznej tudzież poniżyć w opinii publicznej"18. Nie była to szczęśliwa decyzja, dostarczyła bowiem atakującym okazję do ponawiania krytyki, a sam proces stał się de facto sądem nad "Płomykiem" i właściwie potwierdził słuszność stawianych mu zarzutów. Sąd Okręgowy w Warszawie wyrokiem z 4 listopada 1936 r. uniewinnił redaktora odpowiedzialnego „IKC" Jana Stankiewicza, dostrzegając w sowieckim numerze „Płomyka" cechy propagandy. W uzasadnieniu wyroku zapisano: „Niewątpliwie wszystko, co dotyczy ZSRR w nr 25 "Płomyka» przedstawione jest w niezmiernie korzystnym świetle, uśmiechnięte, dobrze ubrane, dzieci w teatrze i szkole, roześmiane twarze w słońcu, dają obraz szczęśliwego kraju. O tym, że obraz taki nie jest zgodny z rzeczywistością nie trzeba mówić tym, którzy w przeciwieństwie do dzieci V i VII oddziałów Szkoły Powszechnej mogą choćby z codziennej pracy [tak w oryginale, być może chodziło o prasę - MW] i innych źródeł czerpać wiadomości"19.

Jeszcze dosadniej wypowiedział się Sąd Apelacyjny, potwierdzający wcześniejszy wyrok. Przywołując uchwały Kominternu sąd surowiej niż oskarżonych osądził stronę skarżącą, czyli wydawców "Płomyka": "Może powstać li tylko pytanie, czy oskarżyciele prywatni świadomie i celowo wydali N. 25 „Płomyka» zgodnie z zaleceniami uchwał 7 Kongresu

17. A. J. Cieślikowa, Wielki skandal polityczny "Płomyka”, "Zeszyty Prasoznawcze" 2004, nr 1-2 (177-178), s. 104-107.

18. AAN, Zespół nr 9, MSW, Sekretariat Ministra, Wydział Bezpieczeństwa, sygn. 829, Materiały dot. działalności ZNP [dalej: AAN, Materiały], Wyrok Sądu Okręgowego w Warszawie z 4 XI 1936.

19. AAN, Materiały, Wyrok Sądu Okręgowego... 
Kominternu"20. Konkluzja wyroku była jednoznaczna i wprost powtarzała prasowe zarzuty: "podejście do dzieci z takimi artykułami i fotografiami, jakie zamieszczone są w N. 25 "Płomyka» jest sączeniem jadu bolszewickiego, zatruwaniem dusz dziecięcych, a więc jest zbrodnią z punktu widzenia polskiej racji stanu"21.

Gdy wydawcy "Płomyka" bronili się tezą, że tym tematycznym numerem chcieli wesprzeć nauczycieli w realizacji programu z geografii, Sąd Okręgowy pytał, gdzie są tam przewidziane programem takie tematy jak Polacy w ZSRS czy kołchozy. A gdy przed Sądem Apelacyjnym bronili się przed zarzutami twierdząc, że przecież opublikowali w tym numerze patriotyczny wiersz Or-Ota List z Sybiru, to szybko okazało się, że z wiersza tego wycięto jedną strofkę, akurat tę mówiącą o nadziei i otusze, jakie na zesłaniu daje wiara i lektura Pisma Świętego. Według Broniewskiej o usunięciu tych słów zadecydował redaktor pisma Mieczysław Kotarbiński, bo wiersz nie mieścił się w szpalcie - uznał więc, że można poświęcić "tę nazbyt nabożną zwrotkę"22. Nawet jeśli ta wersja - potwierdzana zasadniczo przez Wasilewską ${ }^{23}$ - jest prawdziwa i usunięcie strofy wynikało nie z przemyślnego celowego działania, ale z konieczności skrócenia wiersza, to i tak wybór słów do wycięcia jest pewnym świadectwem stosunku działaczy ZNP do religii. Podnosił te argumenty m.in. premier Felicjan Sławoj-Składkowski w przemówieniu w Sejmie 2 grudnia 1938 r., mówiąc: „jakieś brudne, bezczelne ręce opuszczają tę strofkę, wyrzucają ją tendencyjnie, żeby dziecku polskiemu nie dać o tej wierze przeczytać [...] my nie chcemy, żeby nasze dzieci były wychowywane w ten sposób". Jak podaje stenogram, po tych słowach na sali sejmowej zerwały się oklaski i słychać było okrzyki „hańba!"24.

Niefortunne dla "Płomyka" było również zestawienie radosnej ilustracji z okładki sowieckiego numeru z okładką numeru poprzedniego, którego tematem przewodnim była praca. Umieszczono na niej reprodukcję grafiki Stanisława Lentza Strajk, choć podpisanej inaczej - Robotnicy.

20. Tamże, Wyrok Sądu Apelacyjnego w Warszawie; Wydział II Karny, 3 II 1937.

21. AAN, Materiały, Wyrok Sądu Apelacyjnego...

22. Cyt. za: I. Michalska, Czasopisma Związku Nauczycielstwa Polskiego dla dzieci w okresie Drugiej Rzeczypospolitej, Łódź 1994, s. 27.

23. Wspomnienia Wandy Wasilewskiej..., dz. cyt., s. 133.

24. AAN, Materiały", Przemówienie sejmowe premiera Feliksa Sławoja-Składkowskiego, 2 XII 1937, "Biuletyn ogólny”, nr 335, k. 7. 
Wrażenie kontrastu między ciężką dolą robotnika w Polsce a wesołym życiem w Kraju Rad było dość mocne. Również o tym mówił premier w Sejmie, nazywając kłamstwem ilustrowanie poświęconego pracy numeru obrazem robotników w chwili strajku, szczególnie w porównaniu do kolejnego numeru: „w numerze „Płomyka» poświęconego sowietom są przedstawione małe dziewczynki bolszewickie. Daj im Boże zdrowie, ja nie mam w sobie ani cienia zazdrości ani też jakiejkolwiek nienawiści. Niech to dzieci w Sowietach tak wyglądają. Daj Boże. Ale dlaczego przeciwstawiać te wesołe dzieci w Sowietach oto temu obrazowi strajkujących robotników?"25.

Wątpliwości budziła też później sprawa źródła zdjęć ilustrujących ten numer. Podejrzewano - słusznie zresztą - że Wasilewska zdobyła je wykorzystując prywatne kontakty z ambasadą ZSRS, co z kolei rodziło pytanie o udział władz sowieckich w zainicjowaniu i nadaniu kształtu temu numerowi. Broniewska potwierdzała po latach, że materiały fotograficzne Wasilewska otrzymała od attaché prasowego z sowieckiej ambasady, nie widząc zresztą w tym nic złego - „Z ambasadą radziecką, a raczej niektórymi jej pracownikami, łączyły nas od lat przyjacielskie stosunki towarzyskie. Nikt z nas nie musiał konspirować kontaktów kulturalnych, skoro wychodziły książki w przekładach, odbywały się od czasu do czasu całkiem oficjalne przyjęcia, na których bywali co najmniej dalecy od komunizmu pisarze, aktorzy, muzycy i plastycy"26. Nie odpowiadała przy tym na pytanie, czy więzy jej samej i Wasilewskiej z ambasadą nie wykraczały poza przyjacielskie stosunki towarzyskie. W czasie procesu nieoczekiwanie zarzut kontaktów z ambasadą został jednak zneutralizowany przez pracownika agencji prasowej Keyston, który regularnie przekazywał materiały do wydawnictw ZNP i przyznał niezgodnie z prawdą, że te zdjęcia pochodzą z jego agencji. Tak wspominała to wydarzenie Wasilewska: "do dzisiaj nie wiem, czy z nim na ten temat mówiono, czy jemu za to ewentualnie zapłacono, czy też to był sympatyk lub więcej niż sympatyk, który po prostu ratował sytuację, ale on świadomie fałszywie zeznawał"27.

Tymczasem zarzuty o zbyt bliskie kontakty z sowiecką ambasadą nie były wyssane z palca. Nie ulega wątpliwości, że Wasilewska znajdowała się w zasięgu oddziaływania ambasady, że była wśród grupy polskiej

25. AAN, Materiały, Przemówienie sejmowe...

26. J. Broniewska, Tamten brzeg..., dz. cyt., s. 99.

27. Wspomnienia Wandy Wasilewskiej..., dz. cyt., s. 135. 
inteligencji wręcz przez nią inspirowanej. We wspomnieniach złożonych w Zakładzie Historii Partii przy KC PZPR w styczniu 1964 r. mówiła: „Ja sama byłam żyjącym przykładem tego, że jednym z jego [pracownika ambasady Aleksandrowa - MW] zadań - jeżeli chodzi o działalność w Warszawie - była praca z polską inteligencją i on uważał, że jednym z pięknych owoców jego pracy częściowo jestem i ja"28. Co więcej, przyznawała, że w 1936 r. - a więc roku afery "Płomyka" - była przez ambasadę sponsorowana: „kiedy w 1936 r. było u mnie bardzo kiepsko z forsą, to kilkakrotnie ambasada radziecka pomagała mi. Przy czym nazywało się, że to są honoraria za przekłady moich książek, które ukazały się w Związku Radzieckim"29.

Wasilewska, odpowiadając na pytania pracowników Zakładu Historii Partii, nie kryła też, że "Płomyk" ten był formą prosowieckiej propagandy. W czasie któregoś z pobytów w Polsce po wojnie Polskie Radio zaproponowało jej zrobienie reportażu o tej sprawie. Wasilewska przeczytała wówczas ponownie ów numer "Płomyka" oraz krytyczny artykuł z „Ikaca" i ... odmówiła sporządzenia tego reportażu. Dlaczego? Bo nie potrafiłaby wykazać, że numer ten nie był sowiecką propagandą: „Nie napisałam tego reportażu, ponieważ uważałam, że IKC miał stuprocentową rację ze swojego punktu widzenia, bo to była bezczelna sowiecka propaganda"30. I dalej kontynuowała: „A więc ze strony IKC, ze strony rządu, racji stanu oni mieli rację. Dziwiło mnie tylko, że oni nas wszystkich do paki nie zabrali"31.

Obrońcy ZNP starają się pomijać rolę Wasilewskiej przy tym numerze „Płomyka". Działacz i historyk Związku Bolesław Grześ pisze wprost: "Atakujący wiązali omawianą tematykę z osobą Wandy Wasilewskiej posądzanej przez koła konserwatywne o szerzenie wśród związkowców ideologii komunistycznej. Tymczasem W. Wasilewska była redaktorem "Płomyczka», natomiast redaktorem „Płomyka» był Miłosz Kotarbiński"32. To samo twierdził Tomasz Szczechura w wydanym w 1957 r. zarysie dziejów ZNP, pisząc poprawnie imię Kotarbińskiego - Mieczysław ${ }^{33}$. I wszystko

\footnotetext{
28. Wspomnienia Wandy Wasilewskiej..., dz. cyt., s. 4.

29. Wspomnienia Wandy Wasilewskiej... dz. cyt.

30. Wspomnienia Wandy Wasilewskiej..., dz. cyt., s. 130.

31. Wspomnienia Wandy Wasilewskiej... dz. cyt.,

32. B. Grześ, Obrona niezależności Związku Nauczycielstwa Polskiego (65. rocznica zawieszenia działalności ZNP), „Przegląd Historyczno-Oświatowy” $2003 \mathrm{nr}$ 1-2, s. 25.

33. T. Szczechura, Związek Nauczycielstwa Polskiego. Zarys dziejów 1919-1939, Warszawa 1957, s. 221.
} 
to prawda, z formalnego punktu widzenia. W istocie jednak podział pracy między redaktorami „Płomyka" i „Płomyczka" był umowny, a przy tym konkretnym numerze „Płomyka" Wasilewska odegrała decydującą rolę. Potwierdza to Broniewska, potwierdza sama Wasilewska: "Ani Kotarbiński, ani Machowski nie wspominają, uważają, że główny atak będzie skierowany na mnie, a więc rozstrzygają sprawę tak: Oficjalnie było wiadome, że byłam w redakcji „Płomyczka». Nominalnym redaktorem „Płomyka» był Kotarbiński, ale ja robiłam to pismo. Wobec tego zdecydowano, że na procesie wystąpię jako redaktor "Płomyczka», a w «Płomyku» tylko jako korektorka" 34 .

Sprawa „Płomyka" miała też swój sejmowy epizod. Poseł Emeryk Hutten-Czapski - zresztą zeznający jako świadek obrony w czasie procesu - wyraził zaniepokojenie wychwalaniem stosunków komunistycznych przez to pismo i zgłosił zapytanie, co Ministerstwo Wyznań Religijnych i Oświecenia Publicznego zamierza uczynić, aby na przyszłość uniemożliwić „akcję komunizującą wśród dziatwy i młodzieży"35. Po kilku miesiącach minister Wojciech Świętosławski odpowiedział na ręce marszałka Sejmu Stanisława Cara, że ministerstwo zwróciło uwagę kierowników ZNP na niewłaściwość i szkodliwość takich materiałów w czasopiśmie dla młodzieży, a jeśli sytuacja się powtórzy, aprobata tego czasopisma zostanie cofnięta $^{36}$. Po tej wymianie zdań oraz po zakończonym w drugiej instancji procesie wydawców "Płomyka" z „Ikacem" mogło się wydawać, że sprawa już jest zamknięta. Było to jednak na tyle głośne wydarzenie, że obok innych doprowadziło do apogeum napięcia między rządem a związkiem, do którego doszło rok później.

34. Wspomnienia Wandy Wasilewskiej..., dz. cyt., s. 134; Potwierdza to też A. Cieślikowa, Wielki skandal..., s. 106.

35. Dokument 418, Interpelacja posła E. Czapskiego w Sejmie w sprawie numeru tygodnika dla młodzieży „Płomyk", poświęconego ZSRR, 16 III 1936, w: Polsko-radzieckie stosunki kulturalne 1918-1939. Dokumenty i materiały, red. W. Balcerak, Warszawa 1977.

36. Dokument 433, Pismo ministra wyznań religijnych i oświecenia publicznego W. Świętosławskiego do marszałka Sejmu St. Cara z odpowiedzią na interpelację w sprawie tygodnika dla młodzieży „Płomyk", 15 XII 1936, w: Polsko-radzieckie stosunki kulturalne 1918-1939. Dokumenty i materiały, red. W. Balcerak, Warszawa 1977, s. 724 . 


\section{Nie tylko „Płomyk"}

Sprawa sowieckiego numeru „Płomyka" nie była jedynym źródłem kontrowersji wokół ZNP w latach 30. Zarzuty płynące ze strony krytyków związku dotyczyły głównie dwóch kwestii - po pierwsze antyklerykalizmu, po drugie postawy opozycyjnej wobec rządu i kontaktów z lewicą „jednolitofrontową".

Antyklerykalizm - choć podkreślmy, że nie można go przypisywać wszystkim działaczom, zwłaszcza należącym do ZNP nauczycielom - był jednak realnie obecny w związku. Wynikał m.in. z niechęci części środowisk nauczycielskich do wynikającej z zapisów konkordatu obecności katechezy w szkole, konieczności upoważnienia władz kościelnych dla nauczycieli religii czy obowiązku towarzyszenia przez nauczycieli młodzieży przy niektórych praktykach religijnych, o czym stanowił tzw. okólnik Bartla z grudnia 1926 r. ${ }^{37}$ Wasilewska pisała jednoznacznie, choć też wyolbrzymiając: „jedna rzecz była w ZNP bezsporna - dziki, namiętnie gwałtowny antyklerykalizm. Nie należy zapominać, że całą walkę z postępowym nauczycielstwem na wsi prowadził przecież kler i dzięki temu nastroje antyklerykalne były niesłychanie silne" ${ }^{38}$. Antyklerykalne nastawienie i stały konflikt między ZNP a Kościołem i między ZNP a chrześcijańskimi związkami nauczycielskimi - zwłaszcza na terenie wiejskim - potwierdza we wspomnieniach Czesław Wycech ${ }^{39}$. Konflikt z klerem mocno uwidaczniał się np. w województwie śląskim, gdzie do związku należeli raczej nauczyciele przyjezdni z innych regionów, głównie z Małopolski, a miejscowi nauczyciele wybierali w większości Stowarzyszenie Chrześcijańsko-Narodowe Nauczycielstwa Szkół Powszechnych. Jak pisze Anna Glimos-Nadgórska: „Ci spośród jego [ZNP - MW] członków, którzy przybyli do pracy na Śląsk, nie należeli do grona praktykujących katolików, ale nie byli przeciwnikami ani Kościoła, ani religii, inaczej jednak postrzegali ich rolę w życiu codziennym i w życiu szkoły. Nie rozumieli, że dla Górnoślązaków łącznikami z polskością pozostawały w przeszłości m.in. gwara śląska i ścisły związek z Kościołem a zarazem religią w szkole. Z tych to przyczyn

37. B. Grześ, Obrona niezależności..., dz. cyt., s. 23.

38. Wspomnienia Wandy Wasilewskiej..., s. dz. cyt., 133.

39. Cz. Wycech, Wspomnienia..., np. s. 246-249. 
przez miejscową ludność określani byli dość pogardliwie: „te ludzie z Galicji to niepewnej wiary»"40.

Taka postawa prowokowała liczne ataki na ZNP, głównie ze strony publicystów czy pism katolickich. Jednym z głośniejszych był artykuł Edwarda Jamrozika (nie Jamrożka, jak pisze Bolesław Grześ) Na bezdrożach, opublikowany na łamach poznańskiego „Ruchu Katolickiego", wydany później jako osobna broszura w „Biblioteczce Akcji Katolickiej", z doprecyzowaniem tytułu: O nielegalnej działalności Związku Nauczycielstwa Polskiego. Autor przytaczał w nim wiele cytatów z „Głosu Nauczycielskiego" czy zjazdów ZNP świadczących o antyklerykalnym wymiarze działalności tej organizacji, np. słowa o "tworzeniu jednolitego frontu młodzieży wiejskiej, będącej w stanie skutecznie przeciwstawić się wstecznym wpływom na młodzież wiejską organizacji klerykalnych" z uchwały zjazdu delegatów z ZNP z 23 czerwca 1934 roku ${ }^{41}$. Kończył konkretnym wezwaniem: "spodziewać się więc należy, że Komisariat Rządu w Warszawie, jako bezpośrednia władza nadzorcza Związku Nauczycielstwa Polskiego, które jest stowarzyszeniem zarejestrowanym tamże pod nr. 52 [...] względnie w powyższe sprawy i ukróci działalność władz naczelnych Związku Nauczycielstwa Polskiego, wykraczającą przeciwko obowiązującemu prawu (prawu o stowarzyszeniach i ustawie o ustroju szkolnictwa), jak również przeciwko ustalonym w statucie dla tej organizacji zakresowi i sposobom działania (walka z religią, z Kościołem katolickim i z katolickimi stowarzyszeniami)"42. Słusznie zauważa Bolesław Grześ, że był to gotowy scenariusz działania, który wkrótce zaczęły realizować władze. Przesadą jest jednak jego stwierdzenie, że zawarte w artykule "oszczercze oskarżenia nie zasługują na polemikę"43.

Drugi rodzaj zarzutów wobec ZNP to działalność polityczna, opozycyjna wobec rządu. Związek przez długi czas był traktowany raczej jako

40. A. Glimos-Nadgórska, Lewicowy charakter działań podejmowanych przez ZNP $w$ walce o oblicze ideowe szkolnictwa powszechnego w międzywojennym województwie śląskim, w: Polska lewica w XX wieku. Historia - ludzie - idee, red. T. Ślęzak, M. Śliwa, Kraków 2004, s. 113.

41. E. Jamrozik, Na bezdrożach. O nielegalnej działalności Związku Nauczycielstwa Polskiego, Poznań 1937, dz. cyt., s. 5.

42. E. Jamrozik, Na bezdrożach..., dz. cyt., s. 19 .

43. B. Grześ, Obrona niezależności..., dz. cyt., s. 31. 
bliski lewicy sanacyjnej44. W latach 30 . coraz mocniejsze stały się w nim tendencje wyraźnie lewicowe. Związkowa lewica była skupiona przede wszystkim wokół powstałego w 1932 r. Towarzystwa Oświaty Demokratycznej "Nowe Tory". Jej przedstawicielem był działacz ludowy, opowiadający się za frontem ludowym od ludowców przez socjalistów po komunistów, Czesław Wycech. Wiosną 1937 r. Wycech wraz z drugim przedstawicielem tego środowiska Wacławem Tułodzieckim wszedł do Prezydium ZNP45.

Jeszcze mocniej działacze lewicowi byli reprezentowani w Wydziale Wydawnictw ZNP. Sama Wasilewska zastanawiała się, czy mogło być przypadkiem, że w 1934 r. stojący na czele tego wydziału Stanisław Machowski przyjął do pracy cztery osoby związane z lewicą co najmniej tzw. jednolitofrontową, jeśli nie wprost prokomunistyczną? Oprócz Wandy Wasilewskiej została zatrudniona Janina Broniewska, a także Edward Szymański (działacz PPS, Czerwonego Harcerstwa) i Henryk Ładosz ${ }^{46}$.

Wyraźnym dowodem zaangażowania politycznego ZNP był udział w powstaniu "Gazety Wieczornej", przekształconej następnie w marcu 1937 r. w "Dziennik Poranny". Wydawcą była spółdzielnia Oświata, kierowana przez działaczy ZNP Zygmunta Nowickiego i Kazimierza Maja, a sam związek posiadał ok. 1/3 akcji wydawnictwa. Pismo to, redagowane m.in. przez Jana Czarnockiego i Antoniego Wieczorkiewicza, zaliczało się do nurtu lewicy sanacyjnej, współtworzyło obok dzienników PPS i jednolitofrontowego "Dziennika Popularnego" grupę lewicowej prasy codziennej. Oprócz lewicowych piłsudczyków, takich jak Stefan Grostern czy Waldemar Babinicz, współpracował z „Dziennikiem Porannym” m.in. działacz KPP Beniamin Goldberg, publikujący w myśl idei frontu ludowego na łamach pism lewicowych i artystycznych pod fałszywym nazwiskiem jako Jerzy Borejsza. Sam Czarnocki wystąpił z „Dziennika Porannego" we wrześniu 1937 r., a wiosną 1938 r. przestał się on ukazywać na skutek sekwestru nałożonego przez rząd, uznający pismo za jeden z organów frontu ludowego. W tym przypadku nie pomógł kilkutygodniowy strajk dziennikarzy

44. J. Żarnowski, Lewica sanacyjna w latach 1935-1939, "Przegląd Historyczny" 1958 nr 49/4, s. 719.

45. Cz. Wycech, Wspomnienia..., dz. cyt., s. 286-289; B. Grześ, Obrona niezależności..., dz. cyt.,s. 25.

46. Wspomnienia Wandy Wasilewskiej..., dz. cyt., s. 129. 
i pracowników dziennika ${ }^{47}$. Co ciekawe, ówczesny kurator związku Seweryn Maciszewski, o którym jeszcze będzie mowa, udzielił strajkującym zapomogi z funduszu ZNP. Uczynił to, choć wiedział - jak sam później przyznawał - że nie miał do tego prawa, bo formalnie "Dziennik Poranny" nie był ekspozyturą ZNP ${ }^{48}$.

Na koniec dodajmy, że prezydium ZG odrzuciło propozycję dołączenia związku do sanacyjnego Obozu Zjednoczenia Narodowego (OZON), a w prasie ZNP-owskiej pojawiały się artykuły wyraźnie krytyczne wobec tego ugrupowania. Ostatecznie przeważyło szalę i skłoniło rząd do działania opublikowanie w "Głosie Nauczycielskim" artykułu z niewypowiedzianą wprost, acz czytelną tezą, że państwa zaborcze lepiej traktowały nauczycieli niż obecny rząd polski. Tekst ten, autorstwa Wacława Polkowskiego, po opisie założeń Komisji Edukacji Narodowej i następnie sytuacji pod zaborami, z naciskiem na kwestię niezależności nauczycieli od władz, kończył się retorycznym pytaniem „A dzisiaj?"49.

\section{Zawieszenie i strajk}

Wydarzenia z jesieni 1937 r. zostały spopularyzowane przez samą Wasilewską, która w 1950 r. wydała wspomnieniową książeczkę. Jak pisze Broniewska: "«Historia jednego strajku» została napisana przez Wandę na podstawie tego ocalałego archiwum tutaj, w moim mokotowskim mieszkaniu, i wydana dwukrotnie przez „Naszą Księgarnię». Samo archiwum przekazałam z czasem do Zakładu Historii Partii przy KC PZPR, otrzymawszy stosowne pokwitowanie"50. Archiwum strajkowe, z zachowanymi wycinkami prasowymi czy biuletynami strajkowymi, znajduje się dzisiaj w Archiwum Akt Nowych ${ }^{51}$.

Zaczęło się 28 września, gdy do gmachu Zarządu Głównego ZNP przy ul. Smulikowskiego weszło trzech urzędników z zadaniem skontrolowania dokumentacji, zwłaszcza finansowej. Na podstawie ich kontroli

47. A. Paczkowski, Prasa polska w latach 1918-1939, Warszawa 1980, s. 207; A. Notkowski, Prasa Polskiej Partii Socjalistycznej 1918-1939. Przeglad wydawnictw warszawskich, cz. 1, "Kwartalnik Historii Prasy Polskiej" 1988 nr 27/3, s. 79; J. Żarnowski, Lewica sanacyjna..., dz. cyt., s. 722.

48. S. W. Maciszewski, Kartka z dziejów..., dz. cyt., s. 251.

49. J. Żarnowski, Lewica sanacyjna..., dz. cyt., s. 730; W. Polkowski, Dawniej a dziś, "Głos Nauczycielski", 19 IX 1937.

50. J. Broniewska, Tamten brzeg..., dz. cyt., s. 183-185.

51. AAN, Zespół nr 1267, Związek Nauczycielstwa Polskiego, sygn. 133/2, 133/3, 133/4, Komitet Strajkowy. 
29 września został zawieszony Zarząd Główny. 30 września mianowano kuratora rządowego. Formalne przyczyny zawieszenia ZG ZNP i wyznaczenia kuratora zostały podane 2 października $1937 \mathrm{r}$. Wysuwano zasadniczo cztery argumenty. Pierwszy miał charakter polityczny - zarzucano związkowi popieranie i tolerowanie idei i tendencji wyraźnie komunistycznych lub z komunizmem graniczących, popieranie pacyfizmu sprzecznego z założeniami interesów państwa oraz podważanie zaufania do władz państwowych i gloryfikowanie pracy władz zaborczych. Drugi miał charakter społeczny - zarzucano prześladowanie nauczycieli niezgadzających się ze wspomnianymi przekonaniami politycznymi. Trzeci i czwarty argument dotyczyły kwestii formalno-prawnych. Oskarżano władze związku o przekraczanie ram budżetu oraz o użycie pieniędzy ZNP na wydawnictwa polityczne, niemające nic wspólnego ze statutem i sprzeczne z celami związku ${ }^{52}$. Chodziło w tym ostatnim przypadku głównie o opisaną już sprawę „Dziennika Porannego".

Uzasadniając odwołanie zarządu, premier Składkowski odnosił się w przemówieniu sejmowym z 2 grudnia wprost do sprawy "Płomyka": „Ja nie prześladuję żadnych ludzi, nie aresztowałem nikogo, tylko chcę, ażeby uczciwy, patriotyczny, porządny nauczyciel polski na prowincji nie był zmuszony, by podobne paskudztwa przechodziły przez jego ręce do dzieci polskich"53. Słowa te według stenogramu wywołały burzę oklasków - ale pamiętajmy, że Sejm był zdominowany przez obóz rządowy. Widać w nich też próbę wprowadzenia podziału między upolitycznione kierownictwo związku a szeregowych nauczycieli.

Na kuratora związku został wyznaczony Paweł Musioł, stosunkowo młody (31 lat) nauczyciel, śląski pisarz, publicysta i działacz społeczno-polityczny, jedna z ciekawszych postaci w ówczesnym lokalnym życiu kulturalnym. Przed powołaniem na kuratora był nauczycielem w gimnazjum w Katowicach, wcześniej przez trzy lata pracował w Inspektoracie Ochotniczych Drużyn Roboczych w województwie śląskim i w Komendzie Głównej Junackich Hufców Pracy. Usunięty niegdyś z ZNP, Musioł nie był w Warszawie postacią szerzej znaną - to w Katowicach wydawał "Kuźnicę", pismo śląskiej grupy Obozu Narodowo Radykalnego (ONR) „Falanga".

\footnotetext{
52. J. Broniewska, Tamten brzeg..., dz. cyt., s. 208-209; B. Grześ, Obrona niezależności..., dz. cyt., s. 31, 32.

53. AAN, Materiały, Przemówienie sejmowe..., dz. cyt., k. 7.
} 
Tutaj współpracował też ze Związkiem Artystyczno-Literackim w Cieszynie, z Instytutem Śląskim (od 1929 r. był członkiem redakcji "Zarania Śląskiego"). Prowadził wykłady m.in. w Uniwersytecie Powszechnym w Królewskiej Hucie (obecnie Chorzów) i w Katowicach, w Instytucie Oświaty i Kultury im. S. Żeromskiego, w Związku Obrony Kresów Zachodnich. Politycznie związany pierwotnie z ONR, został działaczem Związku Młodej Polski (ZMP), ugrupowania politycznego, które, oderwawszy się od ruchu narodowo-radykalnego, współpracowało z sanacyjnym OZON-em ${ }^{54}$.

Powiązania Musioła z ONR „Falanga", a później członkostwo w posądzanym o ideologiczną z nim zbieżność ZMP pozwoliły stronie związkowej na wysuwanie argumentu, że rząd próbuje podporządkować ZNP konkretnej, i to radykalnie prawicowej, faszystowskiej wręcz organizacji politycznej. Pomogły w tym pewne błędy Musioła. Na przykład, zabezpieczając kasę związku nie miał czym jej zapieczętować, ponieważ nie posiadał jeszcze urzędowej pieczątki - przyłożył więc do pieczęci znaczek ZMP. Zdjęcia tej pieczęci przedostały się później do prasy. Jak wspominała Broniewska, dało to pretekst do głosów o przejęciu ZNP przez ZMP: "Już teraz i my mogliśmy zacząć używać terminu "faszystowski zamach na związki zawodowe» bez obawy, czy z tak "klasową» terminologią w tym konkretnym wypadku pogodzą się nasze miłe, lecz dalekie nawet od socjalizmu urzędniczki"55.

Zarząd Główny ZNP początkowo nie podjął poważniejszych działań przeciw decyzji Komisarza Rządu. W tej sytuacji strajk okupacyjny został zainicjowany przez Janinę Broniewską i Wandą Wasilewską w porozumieniu z pracownikami fizycznymi Wydziału Wydawnictw, drukarzami i zecerami, których reprezentowali Jan Minich i Aleksander Joczys. Około 350 osób zaczęło okupować gmach ZNP. Wkrótce ukonstytuował się komitet strajkowy, którego trzon stanowili Wasilewska, Minich i Joczys oraz dołączona nieco później Broniewska.

3 października strajkujący zostali wyprowadzeni z gmachu ZNP przez policję - obawiając się radykalniejszych protestów środowiska robotniczego, władza wysłała do przeprowadzenia ewakuacji Oddziały Rezerwy Policji Państwowej, przygotowane do tłumienia zamieszek ulicznych

54. L. Jarosz, Musioł Paweł, w: Polski Słownik Biograficzny, t. 22, Wrocław 1977; J. Tomasiewicz, Paweł Musioł, w: Oni tworzyli obraz Górnego Ślaska w XX wieku, red. A. Kubica, J. Mokrosz, Katowice-Rybnik 2017.

55 . J. Broniewska, Tamten brzeg..., dz. cyt., s. 193. 
i demonstracji. Do żadnych ekscesów jednak nie doszło, a uczestnicy strajku przenieśli się do pomieszczeń udostępnionych im przez Związek Zawodowy Kolejarzy ${ }^{5}$.

Taktyka propagandowa rządu polegała na atakowaniu kierownictwa ZNP - za związki z komunizmem i przekręty finansowe. Nie udało się jednak oddzielić Zarządu Głównego od mas członkowskich. Działania władz były postrzegane jako atak na niezależność organizacji nauczycielskiej i na wolności związkowe. Dlatego strajkujących wspierały zarówno środowiska nauczycielskie, jak i inne centrale związkowe. Do jednodniowych demonstracji protestujących wzywali m.in. członkowie zawieszonego zarządu, Zygmunt Nowicki, Czesław Wycech, Wacław Tułodziecki. Pojawiły się protesty w terenie, m.in. w 98 proc. szkół warszawskich. Główna demonstracja poparcia dla strajku w Warszawie nosiła patriotyczny charakter, z udziałem legionistek i peowiaczek na czele, prezentujących Krzyże Walecznych czy Virtuti Militari. Pochód udał się pod Belweder, gdzie złożono kwiaty ku pamięci Józefa Piłsudskiego. Podobne demonstracje odbywały się m.in. w Wilnie i na Lubelszczyźnie ${ }^{57}$.

Udzielili poparcia strajkowi en masse słuchacze znajdujących się w Warszawie instytutów kształcących elitę kadr nauczycielskich - Państwowego Wyższego Kursu Nauczycielskiego, Państwowego Instytutu Nauczycielskiego, Państwowego Instytutu Robót Ręcznych oraz Państwowego Instytutu Pedagogiki Specjalnej. W swojej odezwie pisali o strajkujących: „Walka ich jest nie tylko walką ekonomiczną o utrzymanie warsztatów pracy, jest również protestem przeciw targnięciu się na niezależność związków pracowniczych. Jest to walka o prawa Związku, a więc i o nasze prawa". W akcie solidarności sami deklarowali jednodniowy strajk ${ }^{58}$. Po stronie ZNP stanęły też organizacje związkowe. Wspólną deklarację przeciwko odwołaniu zarządu wystosowały powiązana z ruchem socjalistycznym Komisja Centralna Związków Zawodowych (KCZZ), Centralny Wydział bliższego władzom Związku Związków Zawodowych (ZZZ) oraz Centralna Komisja Porozumiewawcza Pracowników Umysłowych. Z interwencją do premiera Składkowskiego udali się m.in. Tomasz Arciszewski

56. P. Grześ, Obrona niezależności..., dz. cyt., s. 32.

57. S. W. Maciszewski, Kartka z dziejów..., dz. cyt., s. 245.

58. AAN, Związek Nauczycielstwa Polskiego, Komitet Strajkowy, sygn. 133/2, "Biuletyn Informacyjny nr 2 Strejku okupacyjnego pracowników zakładów Związku Nauczycielstwa Polskiego, Warszawa, dnia 2 października 1937 r.", k. 61. 
w imieniu CKW PPS i Jan Stańczyk z ramienia KCZZ. Popierały Związek również niektóre organizacje łączone z lewicą sanacyjną - Federacja Polskich Związków Obrońców Ojczyzny, Związek Pracy Obywatelskiej Kobiet $^{59}$. Podsumowując propagandowy sukces strajkujących, urzędnik ministerstwa Seweryn Maciszewski pisał: „Opinia publiczna kół radykalnych i inteligencji, nie podlegającej wpływom endecji, była całkowicie po stronie ZNP i zawieszonego Zarządu Głównego"60.

Wobec bojkotu kuratora przez ZNP, jednoznacznego stanowiska środowisk nauczycielskich, w tym prezesów okręgowych związku, i przegrywanej de facto propagandowej walki o rację w tym sporze, władze praktycznie przyznały się do porażki i zdecydowały się odwołać Musioła z funkcji. Na jego miejsce minister Wojciech Świętosławski wyznaczył 18 listopada nowego kuratora, którym został wspomniany Seweryn Maciszewski, naczelnik jednego z wydziałów w Ministerstwie Wyznań i Oświecenia Publicznego.

\section{4. Łączność z KPP}

Jak wyglądały związki strajkujących z ruchem komunistycznym? Wanda Wasilewska w swoim opisie strajku nie ukrywa, że pozostawała w stałym kontakcie z Szymonem Natansonem, znanym jej dobrze sekretarzem redakcji pisma frontu ludowego "Dziennik Popularny". Wasilewska znała go z redakcji, w czasie strajku za jego pośrednictwem utrzymywała łączność z KPP. Pierwsze spotkanie z Natansonem odbyła już pierwszego dnia strajku. Tak je później relacjonowała: „Omówiliśmy sprawę pomocy ze strony KPP. Mogła być ona tylko niesłychanie ostrożna i anonimowa. Każda ulotka, każda wydrukowana uchwała, każda przychylna ocena w partyjnej prasie mogła nas zgubić. Z góry było wiadomo, że naszej akcji zechca przyczepić markę komunistyczną, za wszelką cenę trzeba było unikać wszystkiego, co by mogło dać policji choćby pozory dowodów"61. Ustalili wówczas, że jedyną formą kontaktu z partią będą osobiste spotkania z Natansonem, prawie codzienne, na których mieli omawiać poszczególne posunięcia i wymieniać informacje. Komuniści mieli pomagać strajkującym przez swoje wpływy w związkach zawodowych, wśród dziennikarzy czy w innych instytucjach. To spotkanie z "Szymkiem" potwierdza również

59. J. Żarnowski, Lewica sanacyjna..., dz. cyt., s. 730

60. S. W. Maciszewski, Kartka z dziejów..., dz. cyt., s. 245.

61. W. Wasilewska, Historia..., dz. cyt., s. 17. 
Broniewska, pisząc: „Wanda poprosiła Szymka i gdy przyszedł niebawem, odbyli rozmowę tylko we dwoje. W sprawie taktyki i pomocy KPP, żeby nie ułatwić, nie dać żadnej możliwości zdelegalizowania nam strajku. Omówili, jak należy, tylko swoje wyłącznie kontakty, z całą ostrożnością i precyzją"62. W innym miejscu pisze też o "pełnym, choć zakamuflowanym poparciu KPP" dla ich akcji ${ }^{63}$. Gdy zachęty do kontynuowania strajku płynęły równolegle od przywódcy PPS Mieczysława Niedziałkowskiego i od Szymona Natansona, Broniewska mogła zapisać z satysfakcją: „Tak to bezwiednie Niedziałkowski w tej chwili stworzył jednolity front z KPP"64.

Unikanie działań i sformułowań, które bezpośrednio odnosiłyby się do idei czy ruchu komunistycznego, było elementem taktyki ukrywania tych treści i celów, które z jednej strony dałyby argumenty stronie rządowej, a z drugiej zniechęciłyby do strajkujących rzesze niekomunistycznego przecież nauczycielstwa. Broniewska wspominała, jak sama odpowiedziała Wasilewskiej na wątpliwości o używanie zbyt łagodnego, odwołującego się nawet do pamięci o Piłsudskim języka: „Ha, trudno. Gdyby tak zacząć naszym językiem, połowa wróciłaby pod Musioła ze strachu przed komunizmem"65. Obie też z pewną dumą odnotowywały, że w toku strajku udało się skłonić co najmniej do pewnej rewolucyjnej retoryki wielu pracowników ZNP, którzy nie żywili wcześniej sympatii do ruchu komunistycznego. Wasilewska pisała o nauczycielkach, które początkowo nie chciały, by mówić do nich per "towarzyszko", a później z wszystkimi śpiewały Czerwony Sztandar ${ }^{66}$.

Nauczycielski strajk nie miał więc na celu wyłącznie - a może nawet nie przede wszystkim - obrony niezależności ZNP, ale w intencji inspiratorek, Wasilewskiej i Broniewskiej, miał stać się elementem walki szerokiego frontu lewicy społecznej z rządem, a może nawet iskrą do rozpalenia ogólnokrajowego, czy raczej ogólnorobotniczego, rewolucyjnego protestu przeciw rządowi. Protestu, który przybrałby charakter komunistycznej rewolucji. Liczyły na eskalację konfliktu, chciały pozyskać do udziału w nim jak najszersze kręgi środowisk robotniczych. Charakterystyczna była rozmowa, jaką Wasilewska odbyła z kontaktującym się z nią wówczas Janem

62. J. Broniewska, Tamten brzeg..., dz. cyt., s. 193.

63. J. Broniewska, Tamten brzeg..., dz. cyt., s. 215-217.

64. J. Broniewska, Tamten brzeg..., dz. cyt., s. 217.

65. J. Broniewska, Tamten brzeg..., dz. cyt., s. 201.

66. W. Wasilewska, Historia..., dz. cyt., s. 18. 
Kwapińskim, przewodniczącym Komisji Centralnej Związków Zawodowych, największej centrali klasowych związków zawodowych, powiązanej z PPS i żydowskim Bundem. Na zastrzeżenie Kwapińskiego, że postulowany strajk powszechny w obecnej chwili oznaczałby po prostu rewolucję, Wasilewska odpowiada krótko: „No, więc?". Eskalacja, strajk powszechny, w końcu rewolucja - do których dążyła Wasilewska - były tym właśnie, czego chciał uniknąć szef lewicowych związków. Intencje działaczki ZNP były jednoznaczne, a zawód wobec Kwapińskiego i umiarkowanej lewicy z takiego punktu widzenia poważny: „Jeszcze wtedy miałam za dużo złudzeń. Jeszcze wierzyłam, więcej niż krytycznie sądząc niektórych przywódców, że ostatecznym celem PPS jest jednak rewolucja. Dopiero zaczynałam zdawać sobie sprawę, jaką rolę w gruncie rzeczy spełnia Komisja Centralna, rolę hamulca w stosunku do radykalizujących się mas robotniczych, rolę klapy bezpieczeństwa"67.

Czym groził nauczycielski strajk i ewentualne pozyskanie poparcia innych środowisk związkowych zdawał sobie sprawę premier Składkowski. 2 grudnia w Sejmie mówił m.in.: „Kiedy przyszedł do mnie jeden z polityków opozycji po zawieszeniu zarządu i zapytał mnie, czy sobie zdaję sprawę z powagi sytuacji - powiedziałem mu: tak jest, jestem przygotowany na strajk generalny ${ }^{68}$.

Nie miał wątpliwości co do intencji przynajmniej pewnej grupy w ramach ZNP Henryk Glass, działacz harcerski i społeczno-polityczny, od 1925 r. zaangażowany w Porozumienie Antykomunistyczne. Glass, który w czasie wojny będzie wchodził w skład Społecznego Komitetu Antykomunistycznego przy Delegaturze, pisał wprost, że skoro mamy do czynienia ze strajkiem i demonstracjami przeciw rządowi, z kontaktem politycznym z klasowymi organizacjami, z groźbą strajku generalnego - to wyraźnie widać, że ZNP używa środków walki politycznej i rewolucyjnej ${ }^{69}$.

Co ciekawe, kwestia powiązań strajkujących z ruchem komunistycznym w publikacjach po 1989 r. wydaje się zupełnie pomijana. W związanym

67. W. Wasilewska, Historia..., dz. cyt., s. 98. Niestety, nie potrafimy potwierdzić przebiegu tej rozmowy z drugiej strony. W obejmujących ten okres wspomnieniach Jana Kwapińskiego nie ma w ogóle wzmianki o strajku nauczycielskim i kontaktach z Wasilewską. J. Kwapiński, Moje wspomnienia 1904-1939, Paryż 1965.

68. AAN, Materiały, dot. działalności ZNP, Przemówienie sejmowe..., k. 5.

69. H. Glass, Wpływy Kominternu wśród nauczycieli. Materiały oświetlające cele i taktykę komunistów w Związu Nauczycielstwa Polskiego, Warszawa 1938, s. 39. 
z ZNP „Przeglądzie Historyczno-Oświatowym" Grześ neguje udział Wasilewskiej w przygotowaniu sowieckiego numeru "Płomyka" - bo przecież była formalnie redaktorką "Płomyczka" - a przy opisie strajku w ogóle nie wymienia ani jej, ani Broniewskiej. Pisząc o inicjatywie „Dziennika Porannego", nie wspomina o roli tego pisma, o związkach z ruchem frontu ludowego, ograniczając jego rolę do walki o "demokratyzację oświaty i popularyzacji idei szerszych reform gospodarczych i ustrojowych"70. Co więcej, tak wyraźne zaangażowanie polityczne określa pozytywnie jako renesans ideologiczny, zerwanie z "taktyką zgubnej dla szkoły i nauczyciela działalności władz związkowych, ich bezradności i bezczynności"71.

\section{Zwycięzcy i przegrani}

O ile Paweł Musioł starał się po prostu opanować związek i kierować nim, odsuwając tych, którzy przeciw temu protestowali, o tyle nowy kurator, Seweryn Maciszewski, prezentował odmienne stanowisko. Miał postawę koncyliacyjną, chciał doprowadzić jak najszybciej do wyciszenia sporu. Zwołał m.in. prezesów okręgowych ZNP - którzy bojkotowali wcześniej polecenia Musioła - żeby poznać ich stanowiska. Pisał później, że niektórzy - jak prezes Okręgu Pomorskiego Czesław Wycech - prezentowali stanowisko „bojowo-radykalne", ale inni już centrowe czy nawet pojednawcze, jak prezes Okręgu Wołyńskiego, znany później jako Delegat Rządu na Kraj - Jan Stanisław Jankowski ${ }^{72}$.

Maciszewski uznał też wyniki arbitrażu Ministerstwa Opieki Społecznej. Orzeczenie arbitrażu z 30 listopada 1937 r. było pomyślne dla strajkujących - stanowiło, że nieprawnie rozwiązano z nimi umowy, a ich stosunek służbowy pozostał nieprzerwany. Nowy kurator podjął decyzję, że będzie wypłacał pobory zarówno nowym pracownikom, zatrudnionym przez Musioła, jak i wcześniejszym pracownikom, którzy przystąpili do strajku. Tych pierwszych (zwanych pogardliwie przez strajkujących mianem "musiołków") stopniowo do zjazdu ZNP pozwalniał73.

Najważniejszym bowiem zadaniem Maciszewskiego było doprowadzenie do nadzwyczajnego zjazdu delegatów ZNP, który miał wyłonić nowe władze związku. Zjazd ten odbył się 2 lutego 1938 r. w Krakowie.

70. B. Grześ, Obrona niezależności..., dz. cyt.,s. 30.

71. B. Grześ, Obrona niezależności... dz. cyt.,

72. S. W. Maciszewski, Kartka z dziejów..., dz. cyt.,s. 249-250.

73. S. W. Maciszewski, Kartka z dziejów..., dz. cyt.,s. 248. 
Przebiegał w retoryce mocno patriotycznej, wręcz prorządowej, jakby związkowcy chcieli zatrzeć oskarżenia o brak patriotyzmu czy tendencje prokomunistyczne. Śpiewano na Zjeździe Pierwsza Brygadę, składano kwiaty pod kryptą Piłsudskiego, wysyłano adresy do marszałka Edwarda Rydza-Śmigłego i Aleksandry Piłsudskiej. Najważniejsze było jednak powołanie nowego zarządu. Doszło tu do pewnego kompromisu, który miał usatysfakcjonować obie strony. Na nowego prezesa Zarządu Głównego został wybrany Jan Kolanko - czyli prezes sprzed odwołania, co miało dobitnie znaczyć, że członkowie ZNP wciąż nie zgadzają się z wysuwanymi wcześniej zarzutami i udzielają legitymacji zawieszonym władzom związku. Ale jednocześnie, żeby uniknąć upokorzenia władz i sytuacji, gdy odwołany przez nie prezes wciąż pełni swoją funkcję, wykonano gest wobec rządu - Kolanko sam zrezygnował ze stanowiska. Na prezesa został wtedy powołany jego dotychczasowy zastępca Zygmunt Nowicki. Pozostała zatem u steru związku kadra sprzed zawieszenia Zarządu Głównego ${ }^{74}$.

Przy takim kompromisie między rządem a ZNP przegrane okazały się Broniewska, Wasilewska i jeszcze siedmiu liderów strajku, którzy zostali usunięci ze Związku. Tę siódemkę w końcu przyjęto z powrotem, ale już nie dwie inicjatorki: " "Dwie wściekłe baby», jak nazwał nas premier Składkowski, "bez których tamci z Zarządu Głównego ZNP [...] nie ważyliby się nawet pisnąć»"75. Kurator Maciszewski miał świadomość, że nie wszyscy w ZNP podzielają ich poglądy, że istnieje pewien dystans między nimi a resztą działaczy związku: „Wywnioskowałem, że większość byłego Zarządu Głównego ma pełen rezerwy, żeby nie powiedzieć więcej, stosunek do byłych redaktorek "Płomyka» i «Płomyczka» i nie zamierza przy powrocie do rządów w ZNP kruszyć kopie o utrzymanie tych pań na zajmowanych poprzednio stanowiskach"76. Ostatecznie 1 maja 1938 r. Wasilewska i Broniewska zostały zwolnione z trzymiesięcznym wypowiedzeniem. W proteście rozpoczęły własny strajk, przyjęły formę głodówki. Gdy niektórzy pracownicy chcieli dołączyć do głodówki, one przerwały - jak później tłumaczyły - żeby ich nie męczyć i nie dopuścić do lokautu ${ }^{77}$.

74. T. Szczechura, Związek Nauczycielstwa..., dz. cyt., s. 244-245.

75. J. Broniewska, Tamten brzeg..., dz. cyt.,s. 219.

76. S. W. Maciszewski, Kartka z dziejów..., dz. cyt.,s. 253.

77. W. Wasilewska, Historia..., dz. cyt.,s. 178-183; J. Broniewska, Tamten brzeg..., dz. cyt.,s. 241. 
W artykule opublikowanym na łamach "Życia Literackiego" w PRL, w 50. rocznicę sowieckiego numeru "Płomyka", na pytanie: "Czego się ówczesne władze obawiały?" odpowiadano: "Ano, chyba prawdy, z którą $\mathrm{w}$ «Płomyku» wyszli redaktorzy tego dziecięcego pisma do polskich dzieci i młodzieży"78. Ano, nie prawdy, tylko jej przeinaczania i realnych wpływów środowisk komunistycznych w najważniejszej organizacji nauczycielskiej, na co starałem się zwrócić uwagę. Rząd jednak z tego sporu wyszedł przegrany, wiele utracił w opinii publicznej, nie udało mu się przekonać społeczeństwa, ale przede wszystkim rzesz nauczycielskich do swoich racji. Błędem było wyznaczenie na pierwszego kuratora raczej działacza politycznego niż urzędnika, co dało pretekst do protestów i tezy o "faszystowskim" zamachu na związek. Można zakładać, że niepowiązany z konkretnym ugrupowaniem politycznym urzędnik ministerstwa nie wzbudziłby takiego oporu i być może łatwiej opanowałby sytuację. Przy tej porażce rządu honor ratowało mu usunięcie Kolanki z funkcji prezesa oraz inicjatorek strajku z Wydziału Wydawnictw ZNP - bez Broniewskiej i Wasilewskiej wpływy KPP czy ruchu „jednolitofrontowego" na związek rzeczywiście zmalały. Wygrał za to spór ZNP w wymiarze całej organizacji, broniąc się przed oskarżeniami o komunizm, umacniając poczucie nauczycielskiej solidarności i rolę w ruchu związkowym. Przegrały natomiast z osobistego punktu widzenia Wasilewska i Broniewska, które nie wróciły już do pracy w Związku.

\section{Zakończenie}

Czasem odkrywania kart i ostatecznych wyborów była II wojna światowa. Dopisała też swoisty epilog do starcia dwóch głównych osobistych oponentów z 1937 r. - niefortunnego kuratora ZNP Pawła Musioła i organizatorki strajku Wandy Wasilewskiej. Musioł włączył się w nurt działalności niepodległościowej na Śląsku Cieszyńskim, najpierw w Tajnej Organizacji Wojskowej, następnie w ZWZ, pełniąc m.in. funkcję inspektora Inspektoratu Cieszyńskiego. Wytropiony przez Niemców, został aresztowany w marcu $1941 \mathrm{r}$. Wasielewska natomiast w 1939 r. uciekła na tereny okupowane przez ZSRS, gdzie przyjęła obywatelstwo sowieckie i wstąpiła do Wszechzwiązkowej Komunistycznej Partii (bolszewików). W lutym 1943 r. współtworzyła Związek Patriotów Polskich, mający stać się w ręku Stalina narzędziem do realizacji

78. W. Mielczarek, Sprzed 5o. lat. Konfiskata "Płomyka" Wasilewskiej, "Życie Literackie", 2 III 1986. 
planu podporządkowania i skomunizowania Polski. Dokładniew tym czasie, 19 lutego 1943 r., Musioł - wielokrotnie określany przez Wasilewską mianem faszysty - kładł głowę pod gilotyną w niemieckim więzieniu w Katowi$\operatorname{cach}^{79}$.

79. A. Jarosz, Musioł Paweł..., dz. cyt. 


\section{Bibliografia}

Archiwalia i wspomnienia niepublikowane

AAN, Zespół nr 9, MSW, Sekretariat Ministra, Wydział Bezpieczeństwa, sygn. 829, Materiały dot. działalności ZNP.

AAN, Zespół nr 1267, Związek Nauczycielstwa Polskiego.

Wspomnienia Wandy Wasilewskiej (nagrane w Zakładzie Historii Partii

przy KC PZPR w styczniu 1964 r.), (udostępnione przez M. Korkucia, kopia w posiadaniu autora).

Artykuły i opracowania

J. Broniewska, Tamten brzeg mych lat, Warszawa 1979.

A. J. Cieślikowa, Wielki skandal polityczny "Płomyka", "Zeszyty

Prasoznawcze" 2004 nr 1-2, s. 177-178.

I. Desperak, Strajk przeciwko złej zmianie, http://krytykapolityczna.pl/

kultura/historia/strajk-przeciwko-zlej-zmianie/ (26.06.2017).

H. Glass, Wpływy Kominternu wśród nauczycieli. Materiały oświetlajace cele i taktykę komunistów w Związku Nauczycielstwa Polskiego, Warszawa 1938.

A. Glimos-Nadgórska, Lewicowy charakter działań podejmowanych przez ZNP ${ }_{w}$ walce o oblicze ideowe szkolnictwa powszechnego w międzywojennym województwie śląskim, w: Polska lewica wXX wieku. Historia - ludzie - idee, red. T. Ślęzak, M. Śliwa, Kraków 2004, s. 112-118.

B. Grześ, Obrona niezależności Związku Nauczycielstwa Polskiego (65. rocznica zawieszenia działalności ZNP), "Przegląd Historyczno-Oświatowy" 2003 nr 1-2, s. 21-35.

E. Jamrozik, Na bezdrożach. O nielegalnej działalności Związku

Nauczycielstwa Polskiego, Poznań 1937.

L. Jarosz, Musioł Paweł, w: Polski Słownik Biograficzny, t. 22, Wrocław 1977.

J. Kwapiński, Moje wspomnienia 1904-1939, Paryż 1965. 
S. W. Maciszewski, Kartka z dziejów kryzysu w ZNP (1937-1938), "Rozprawy z Dziejów Oświaty XLI" (2002), s. 243-253.

I. Michalska, Czasopisma Związku Nauczycielstwa Polskiego dla dzieci w okresie Drugiej Rzeczypospolitej, Łódź 1994.

A. Notkowski, Prasa Polskiej Partii Socjalistycznej 1918-1939. Przegląd wydawnictw warszawskich, cz. 1, „Kwartalnik Historii Prasy Polskiej" $1988 \mathrm{nr} 27 / 3$, s. 5-49.

Oni tworzyli obraz Górnego Śląska wXX wieku, red. A. Kubica, J. Mokrosz, Katowice-Rybnik 2017.

A. Paczkowski, Prasa polska w latach 1918-1939, Warszawa 1980.

Polsko-radzieckie stosunki kulturalne 1918-1939. Dokumenty i materiały, red. W. Balcerak, Warszawa 1977.

T. Szczechura, Związek Nauczycielstwa Polskiego. Zarys dziejów 1919-1939,

Warszawa 1957.

W. Wasilewska, Historia jednego strajku, Warszawa 1950.

C. Wycech, Wspomnienia 19o5-1939, Warszawa 1969.

J. Żarnowski, "Lewica sanacyjna” w latach 1935-1939 , "Przegląd Historyczny" $1958 \mathrm{nr}$ 49/4, s. 714-737.

Prasa

„Płomyk", 2 III 1936.

"Ilustrowany Kurier Codzienny", 7 III 1936.

"Życie Literackie", 2 III 1986.

"Głos Nauczycielski", 19 IX 1937. 


\title{
Abstract
}

\author{
Michał Wenklar \\ Between the defence of freedom and the road to \\ revolution. The teacher's strike of 1937
}

\author{
Keywords: \\ ZNP, Polish \\ Teachers' \\ Union, Wanda \\ Wasilewska, Paweł \\ Musioł, Płomyk, \\ the People's \\ Front, KPP, Polish \\ Communist Party.
}

In March 1936, a Soviet edition of the youth periodical "Płomyk" was published. Some papers of that time denounced it as a part of the Soviet propaganda. To defend their good name, the publishers of the periodical sued one of such newspapers, but they lost the case. A year and a half later, in September 1937, the government suspended the Executive Board of Polish Teachers' Union (ZNP) and appointed an administrator. One of the charges, along with financial inaccuracies, was that the organization harboured pro-communist political sympathies.

In response to the government's actions, some of the members of the Executive Board organized a sit-in, soon followed by teachers and many trade unions as well political organizations. The strike proved successful. First, the government pulled out on the previous appointment and assigned a new administrator. Subsequently, the Polish Teacher's Union convention appointed a new Executive Board, composed of key pre-strike activists.

For activists closely connected with the ZNP, government's activities constituted an attempt to curb trade union liberties, and the industrial action was merely an act of defence of freedom and civil liberties. However, one can find traces of the Polish Communist Party's direct contacts with strike initiators can and their aspirations, at least in the case of certain activists such as Wanda Wasilewska and Janina Broniewska, to escalate the conflict and call a general strike.

516 Folia Historica Cracoviensia, t. 23, z. 2 (2017) 


\section{Abstrakt}

Michał Wenklar

Między obrona wolności a droga do rewolucji.

Strajk nauczycielski 1937 roku

W marcu 1936 r. ukazał się poświęcony Związkowi Sowieckiemu numer wydawanego przez ZNP czasopisma dla młodzieży „Płomyk". Część ówczesnej prasy określiła go jako element sowieckiej propagandy. W obronie swojego dobrego imienia wydawcy pisma wytoczyli jednej z gazet proces, który przegrali. Półtora roku później, we wrześniu 1937 r., rząd zawiesił Zarząd Główny ZNP i wyznaczył kuratora. Jednym z zarzutów, oprócz tych dotyczących nieprawidłowości finansowych, były prokomunistyczne sympatie polityczne.

W odpowiedzi na działania rządu część pracowników Zarządu Głównego zorganizowała strajk okupacyjny, wkrótce poparty przez samych nauczycieli i wiele organizacji związkowych i politycznych. Strajk okazał się zwycięski, najpierw rząd odwołał dotychczasowego i powołał nowego kuratora, a następnie zjazd ZNP wyłonił nowy Zarząd Główny, złożony z kluczowych działaczy sprzed strajku.

Dla badaczy bliskich ZNP działania rządu stanowiły zamach na wolności związkowe, a strajk miał charakter jedynie obrony wolności i swobód obywatelskich. Można jednak odnaleźć ślady bezpośrednich kontaktów KPP z inicjatorkami strajku i dążeń - przynajmniej niektórych działaczy, jak Wanda Wasilewska i Janina Broniewska - do eskalacji konfliktu i wywołania strajku generalnego.

\section{Słowa kluczowe:} ZNP, strajk, Wanda Wasilewska, Paweł Musioł, „Płomyk", front ludowy, KPP. 
